Table 2. Distribution of plasma-protein values for men and non-pregnant and pregnant women

\begin{tabular}{|c|}
\hline $\begin{array}{c}\text { Plasma } \\
\text { protein } \\
\text { (g./100 ml.) }\end{array}$ \\
\hline $\begin{array}{l}5 \cdot 0-5 \cdot 4 \\
5 \cdot 5-5 \cdot 9 \\
6 \cdot 0-6 \cdot 4 \\
6 \cdot 5-6 \cdot 9 \\
7 \cdot 0-7 \cdot 4 \\
7 \cdot 5-7 \cdot 9 \\
8 \cdot 0-8 \cdot 4 \\
8 \cdot 5-8 \cdot 9\end{array}$ \\
\hline
\end{tabular}

Men
$(378)$
(percentage
of total)
0
0.3
2.4
15.9
47.1
26.2
7.0
1.0

Women
(553)
(percentage
of total)
0
0.2
0.2
4.0
26.6
50.9
17.0
1.2

Pregnant
women $(300)$
(percentage
of total)
$1 \cdot 0$
$7 \cdot 0$
$38 \cdot 5$
$39 \cdot 5$
$12 \cdot 5$
$1 \cdot 5$
-

moderate degree of anaemia during pregnancy as physiological, and a figure of $10 \mathrm{~g} . /$. $100 \mathrm{ml}$. is taken as the lowest limit of normality. On this basis $8.2 \%$ of the subjects examined were suffering from a more severe grade of anaemia than could be accounted for by their pregnancy.

The plasma-protein values for pregnant women were also lower than those for the subjects in the first group, but only $8 \%$ fell below the accepted lowest level for the normal adult. If, as is generally agreed, the haemoglobin concentration is lowered because of hydraemia this condition would also depress the plasma-protein concentration so that we might be justified in regarding a figure of $5.5 \mathrm{~g} . / 100 \mathrm{ml}$. as representing a physiological hypoproteinaemia. On this basis only I \% of our subjects would fall below the normal range.

This work was carried out with the aid of a grant from the Medical Research Council of Ireland.

\title{
REFERENCES
}

Department of Health (Republic of Ireland) ( $1949 a$ ). Methods of Dietary Survey and Results from Dublin Investigation. Dublin: The Stationery Office.

Department of Health (Republic of Ireland) (1949b). Dietary Survey of the Congested Districts. Dublin: The Stationery Office.

Department of Health (Republic of Ireland) (r 950 a). Dietary Surcey of Large and Small Touns. Dublin: The Stationery Office.

Department of Health (Republic of Ireland) (1950b). Dietary Survey of Farming Families. Dublin: The Stationery Office.

Jessop, W. J. E. (1950). Brit. Ұ. Nutrit. 4, 281.

Phillips, R. A., Van Slyke, D. D., Dole, V. P., Emerson, K. Jr., Hamilton, P. B. \& Archibald, R. M. (r945). Copper Sulfate Method for Measuring Specific Gravities of Whole Blood and Plasma. New York: Josiah Macy Jr. Foundation.

Wintrobe, A. M. (1942). Clinical Haematology. London: Henry Kimpton.

\section{Results of Rickets Surveys in Dublin}

By W. J. E. Jessop, Royal College of Surgeons in Ireland, St Stephen's Green, Dublin

During the autumn of 1942 radiologists and clinicians noticed a rise in the incidence of rickets in Dublin. Between September 1940 and February 1942, the extraction rate of flour had been increased from its prewar level of $70-72 \%$ to $100 \%$ and Harrison \& Mellanby (1939) and McCance \& Widdowson (1942-3) had shown that this might have a very adverse effect on calcium absorption. In addition, the importation of cod- 
liver oil and other more concentrated sources of vitamin $D$ had fallen considerably because of the war. It was therefore thought worth while to attempt to find out the extent to which rickets had increased and to note any changes in the incidence that might follow changes in the extraction rate of flour and in the intake of vitamin D.

No figures were available for the incidence before this question arose. The most reliable records available were those of the radiological departments of the children's hospitals. These records were examined over the periods I August 1939-31 July I 940 and I August 1941-31 July 1942, and it was found that the incidence in the second period was more than double that in the first. 'I 'he mothers of the majority of the children that had had rickets in the second period were emphatic that the child concerned had received the same diet as his elder brothers and sisters who had shown no sign of the disease. None of the children that had developed rickets had received cod-liver oil regularly, but then neither had any of their elder brothers and sisters. The staple diet in all cases was bread and butter. Consequently it seemed more likely that the increase in rickets was related to the increase in the extraction rate of flour than to a decrease in the intake of vitamin D.

During the spring months of each year from 1943 to 1948 inclusive a survey of the incidence of rickets was carried out (Pringle, Reynolds \& Jessop, 1943; Croasdaile, Collis, Pringle \& Jessop, 1943; Fitzgerald, Sheehan, Collis, Pringle, Reynolds \& Jessop, I944; Grove-White, Sheehan, Collis, Pringle, Reynolds, Douglas \& Jessop, 1945; Walsh, Kidney, Collis, Pringle, Reynolds, Douglas \& Jessop, 1946; Epstein, Kidney, Collis, Pringle, Reynolds, Douglas \& Jessop, 1950). Random samples were taken of children between the ages of 3 months and 4 years attending the out-patient departments of the three children's hospitals and one of the largest childwelfare centres. Those out-patient sessions that were especially likely to be attended by children suffering from rickets were avoided. Each child in the sample had one wrist $\mathrm{X}$-rayed. The films were examined by a committee of radiologists, and the cases of active and healing rickets noted. When the radiological diagnosis was in doubt an estimation of plasma alkaline phosphatase was done if possible and cases with a result of 20 King-Armstrong units or more were regarded as positive. Doubtful cases in which plasma-phosphatase estimations could not be done were regarded as negative. The size of the samples in each age group in the various centres was kept fairly constant from year to year but in a few instances there were significant variations. For the purpose of presenting the results of the series the incidences were 'standardized' on the assumption that the number in each group was constant throughout and was the average for that group over all the surveys.

The changes in the incidence followed the same pattern in each of the centres examined. Consequently, in Table I, the incidence for each age group is presented from all centres taken together.

Whereas the incidence of rickets in children of $\mathrm{I}$ year and under fell very little between 1943 and $I 948$, the incidence in children from $\mathrm{I}$ to 4 years fell very considerably.

At the time of the X-ray examination each mother was asked how much milk her child was accustomed to get and what vitamin concentrates it was receiving. It was thought unlikely that a child would get rickets if it were receiving $\frac{3}{4}$ pt. milk and $400 \mathrm{i} . \mathrm{u}$. 
Table I. Incidence of rickets in Dublin during the period 1943-8

\begin{tabular}{|c|c|c|c|c|c|c|c|}
\hline \multirow[b]{2}{*}{ Age group } & \multirow{2}{*}{$\begin{array}{c}\text { Average } \\
\text { no. } \\
\text { examined } \\
\text { yearly } \\
\text { I } 943-8\end{array}$} & \multicolumn{6}{|c|}{$\begin{array}{l}\text { Standardized incidences per } 1000 \text { in children from three } \\
\text { children's hospitals and one child-welfare centre }\end{array}$} \\
\hline & & I 943 & 1944 & I945 & 1946 & 1947 & 1948 \\
\hline 3-6 months & 50 & 203 & $216^{\circ}$ & 88 & 82 & 126 & 62 \\
\hline 7-12 months & 85 & 155 & 326 & 160 & 227 & 168 & 227 \\
\hline 13-18 months & 70 & 182 & 186 & 170 & 109 & 97 & 50 \\
\hline 19-24 months & 60 & $35^{\circ}$ & 152 & 67 & 153 & 72 & 58 \\
\hline $2-3$ years & 85 & 168 & 113 & 41 & 52 & 20 & 0 \\
\hline $3-4$ years & 80 & 60 & 115 & 49 & 49 & 14 & II \\
\hline All ages & 430 & 173 & 180 & 96 & 113 & 80 & 70 \\
\hline
\end{tabular}

vitamin $\mathrm{D}$ daily and these amounts were judged adequate if they had been given for at least 2 months before the date of examination. It was therefore possible to calculate for each year the proportion of children in each group that had had an adequate intake of milk and vitamin D, and these figures are given in Table 2.

Table 2. Relation of incidence of rickets to intake of milk and vitamin $D$ in children of $\mathrm{I}$ year and under and in children from $\mathrm{I}$ to 4 years

\begin{tabular}{|c|c|c|c|c|c|c|}
\hline \multirow[b]{3}{*}{ Year } & \multicolumn{3}{|c|}{ Children aged I year and under } & \multicolumn{3}{|c|}{ Children from 1 to 4 years } \\
\hline & \multirow{2}{*}{$\begin{array}{l}\text { Incidence } \\
\text { per } 1000\end{array}$} & \multicolumn{2}{|c|}{$\begin{array}{l}\text { Percentage with in- } \\
\text { adequate intake* of }\end{array}$} & \multirow{2}{*}{$\begin{array}{l}\text { Incidence } \\
\text { per } 1000\end{array}$} & \multicolumn{2}{|c|}{$\begin{array}{l}\text { Percentage with in- } \\
\text { adequate intake of }\end{array}$} \\
\hline & & Milk & Vitamin D & & Milk & Vitamin D \\
\hline 1943 & 174 & 73 & 15 & 172 & 39 & 29 \\
\hline 1944 & 250 & 63 & 34 & I 39 & 39 & 36 \\
\hline 1945 & I 33 & 96 & 40 & 79 & 69 & 49 \\
\hline 1946 & 173 & 95 & 28 & 85 & $5^{8}$ & 40 \\
\hline 1947 & 153 & 88 & 19 & 47 & 64 & 35 \\
\hline 1948 & 166 & 87 & 23 & 27 & 69 & 44 \\
\hline
\end{tabular}

Dr Geary, of the Statistics Branch, Department of Industry and Commerce, informs me that when this point is examined statistically neither inadequate milk alone nor inadequate vitamin $\mathrm{D}$ alone is significantly related to the incidence of rickets but that combined inadequacy of both has a significant relationship.

For the purpose of examining the possible relationship of the extraction rate of flour to incidence of rickets Table 3 was constructed in which the effects on available calcium of the phytate in high-extraction flour and of calcium added as acid calcium-phosphate have been combined.

Following the realization that the incidence of rickets had reached such a dangerously high level, the extraction rate of flour was reduced to $85 \%$, and this was associated with a fall in rickets in children over I year. A second fall followed the fortification of baker's flour with acid calcium-phosphate.

It is suggested that the high incidence in children under I year is related to their low intake of vitamin $\mathrm{D}$, and that the phytate content of high-extraction flour was a significant factor in determining the sharp increase in cases of rickets in children from $\mathrm{x}$ to 4 years that occurred in the period $194 \mathrm{I}-3$. 
Table 3. Relation of available calcium and incidence of rickets to extraction rate and fortification level of flour

\begin{tabular}{|c|c|c|c|c|}
\hline $\begin{array}{l}\text { Dates when changes } \\
\text { made and surveys } \\
\text { carried out }\end{array}$ & $\begin{array}{l}\text { Extraction } \\
\text { rate of } \\
\text { flour }\end{array}$ & $\begin{array}{c}\text { Added } \\
\text { calcium } \\
\text { (mg./oz. bread) }\end{array}$ & $\begin{array}{c}\text { Available } \\
\text { calcium* } \\
\text { (mg./oz. bread) }\end{array}$ & $\begin{array}{c}\text { Incidence } \\
\text { of rickets } \\
\text { per } 1000 \text { in } \\
\text { children over } \\
\text { I year }\end{array}$ \\
\hline Up to Sept. 1940 & 70 & $\circ$ & $5 \cdot 7$ & - \\
\hline Sept. 1940 & 75 & $\circ$ & $5 \cdot 3$ & - \\
\hline Jan. 1941 & 80 & 0 & 3.4 & - \\
\hline Feb. I94 I & 90 & 。 & $-1 \cdot 4$ & - \\
\hline Mar. 1941 & 95 & $\circ$ & $-6 \cdot 0$ & - \\
\hline Feb. 1942 & 100 & $\circ$ & $-11 \cdot 0$ & - \\
\hline Feb. to Apr. 1943 & 100 & 0 & $-11 \cdot 0$ & 172 \\
\hline Dec. 1943 & 85 & $\circ$ & $2 \cdot 4$ & - \\
\hline Feb. to Apr. 1944 & 85 & $\circ$ & $2 \cdot 4$ & 139 \\
\hline Feb. to Apr. 1945 & 85 & 0 & $2 \cdot 4$ & 79 \\
\hline Nov. 1945 & 80 & 0 & 3.4 & - \\
\hline Feb. 1946 & 85 & $\circ$ & $2 \cdot 4$ & - \\
\hline Feb. to Apr. 1946 & 85 & o & $2 \cdot 4$ & 85 \\
\hline Apr. 1946 & 90 & 0 & $-1 \cdot 4$ & - \\
\hline June 1946 & 90 & 19 & $17 \cdot 6$ & - \\
\hline Nov. 1946 & 90 & 10 & $8 \cdot 6$ & - \\
\hline Jan. 1947 & 85 & 10 & $12 \cdot 4$ & - \\
\hline Feb. to Apr. $19+7$ & 85 & 10 & $12 \cdot 4$ & 47 \\
\hline Feb. to Apr. 1948 & 85 & 10 & 12.4 & 27 \\
\hline
\end{tabular}

- Calculated on the assumption that calcium bound as hexacalcium phytate is not available.

The various surveys were carried out with the aid of grants from the Medical Research Council of Ireland, the Medical Association of Eire and the Marrowbone Lane Samaritan Fund.

\section{REFERINCES}

Croasdaile, H. V., Collis, W. R. F., Pringle, H. \& Jessop, W. J. E. (1943). J. med. Ass., Eire, 12, 69. Epstein, M. R., Kidney, W., Collis, W. R. F., Pringle, H., Reynolds, R. A., Douglas, S. \& Jessop, W. J. E. (1950). F. med. Ass., Eire, 26, 19.

Fitzgerald, H. D., Sheehan, N. E., Collis, W. R. F., Pringle, H., Reynolds, R. A. \& Jessop, W. J. E. (1944). F. med. Ass., Eire, 15, 54 .

Grove-White, M. L., Sheehan, N. E., Collis, W. R. F., Pringle, H., Reynolds, R. A., Douglas, S. \& Jessop, W. J. E. (1945). Y. med. Ass., Fire, 17, 159.

Harrison, D. C. \& Mellanby, E. (1939): Biochem. F. 33, 1660.

McCance, R. A. \& Widdowson, E. M. (1942-3). Y. Physiol. ror, 44.

Pringle, H., Reynolds, A. A. \& Jessop, W. J. E. (1943). J. med. Ass., Eire, 12, 67.

Walsh, J. P., Kidney, W., Collis, W. R. F., Pringle, H., Reynolds, R. A., Douglas, S. \& Jessop, W. J. E. (1946). 9. med. Ass., Eire, 19, 156.

\section{Practical Significance of the Irish National Nutrition Survey}

By J. Deeny (Chief Medical Adviser, Department of Health, Government of Ireland), Customs House, Dublin

I shall commence these remarks with the trite observation that the administrative approach to a survey such as the Irish National Nutrition Survey (Department of Health (Republic of Ireland), 1949a, $b, 195 \circ a, b$ ) is very different from that of the investigator or nutritional specialist. Whereas it is the task of the research worker or investigator 